\title{
Magnitude of Ornithine Decarboxylase Induction by Epidermal Mitogens: Effect of the Assay Technique
}

\author{
D. I. Roseeuw ${ }^{1}$, C. L. Marcelo ${ }^{2}$, and J. J. Voorhees ${ }^{2}$ \\ 1 Department of Dermatology, Vrije Universiteit, Brussels, Belgium \\ 2 Department of Dermatology, University of Michigan Medical School, Ann Arbor, Michigan, USA
}

Summary. The polyamines, putrescine, spermidine and spermine, as well as ornithine decarboxylase (ODC), the rate-limiting enzyme of polyamine biosynthesis, are increased in the blood, urine and skin of psoriasis patients. A study of the association between stimulated epidermal cell proliferation and induction of ODC activity was done using both an intact, living cell ODC assay and the routinely used homogenized cell supernate assay. $10^{-6}$ to $10^{-8} \mathrm{~mol} / 1$ of the tumor promoter, tetradecanoyl phorbol acetate (TPA), $10^{-3} \mathrm{~mol} / 1$ 8-BrcAMP, $10^{-6} \mathrm{~mol} / 1$ cholera toxin and $10^{-3} \mathrm{~mol} / 1$ MIX, which are epidermal cell mitogens, were used to stimulate basal cells in short-term suspension cultures, freshly plated monolayers, or up to 8-day-old cultures. The results showed that the ODC enzyme must be assayed in supernates from disrupted epidermal cells in order for significant ODC induction by hyperplastic agents to be observed.

Key words: ODC - Epidermis - Cyclic nucleotides TPA - Intact cell assay

Both normally growing and neoplastic cells show increased intracellular amounts and secretion of the polyamines, putrescine, spermidine and spermine $[3,30]$. The rate-limiting enzyme in polyamine biosynthesis is ornithine decarboxylase (ODC; EC 4.1.1.17), which catalyzes the synthesis of putrescine and $\mathrm{CO}_{2}$ from the diamine ornithine. This enzyme is induced in normal hyperproliferative states [2], in hyperproliferative epidermal diseases $[26,31,32]$, and human cutaneous epitheliomas [34].

Studies using a number of in vivo and in vitro cell systems show that when cells are treated with the tumor

Offprint requests to: Diane I. Roseeuw, MD, Adjunkt Kliniekhoofd, Department of Dermatology, A.Z. V.U.B., Laarbeeklaan 101, B-1090 Brussels, Belgium promoter, tetradecanoyl phorbol acetate (TPA) $[22,41]$, cyclic AMP analogs [10, 12], the divalent cation ionophore A 23187 [17], or serum [7, 12], ornithine decarboxylase activity is induced. These substances are also epidermal cell mitogens $[6,11,12,14,15,33,40]$. Therefore, a direct correlation between epidermal hyperplasia and ODC induction may exist; additionally, polyamines have also been implicated in the differentiation of several cell types $[35,36]$.

Other intracellular mediator systems appear to be involved in polyamine-associated hyperproliferation. The release of arachidonic acid and its product prostaglandin (PG) $E_{2}$ is necessary for TPA stimulation of epidermal cell proliferation $[4,5]$ and for induction of ODC activity [38] to occur. Moreover, these TPAinduced events are probably linked to the calcium metabolism of the epidermal cell $[18,37]$.

The role of cyclic nucleotides in these events, i.e., TPA induction of ODC activity, hyperplasia and tumor promotion, is still unknown and numerous studies reporting conflicting data have appeared over the last 5 years $[19,20,24,25]$.

In our investigation of the association between stimulated epidermal cell proliferation and the induction of ODC activity, we used two ODC assay techniques: one was an intact cell ODC assay recently developed by us [27] and similar to the one described by Patterson and Maxwell [23], and the second was the routinely used disrupted cell supernate assay [41]. Additionally, several neonatal mouse basal cell systems were studied. Our results, presented in this report, indicated that a significant induction of epidermal cell ODC activity by a hyperproliferative stimulus was seen only when the enzyme was isolated from the cells by homogenization or sonification. Intact cell ODC analyses of stimulated, living epidermal cells in suspension or monolayer showed a complete dissociation between TPA and cyclic AMP stimulated epidermal cell proliferation and the induction of ODC activity. 


\section{Materials and Methods}

\section{Reagents}

Neonatal mice were obtained from the Department of Dermatology of the University of Michigan Medical School (BALB/c colony). Medium 199 (M-199), Eagle's medium (modified with Earle's salt, with glutamine), fetal bovine serum (FBS), penicillin and streptomycin (P \& S), and phosphate-buffered saline (PBS, Dulbecco's) were from Flow Laboratories, McLean, VA, USA. Trypsin (bovine pancreas type III), soybean trypsin inhibitor type I-S, Ficoll 400, 8-bromoadenosine- $3^{\prime}, 5^{\prime}$-cyclic monophosphoric acid (8-BrcAMP), 12-O-tetradecanoylphorbol-13-acetate (TPA), and dimethylsulfoxide were obtained from Sigma Chemical Company, St. Louis, MO, USA.

Cholera toxin (CT) was obtained from Schwarz Mann, Orangeburg, NY, USA; 3-isobutyl-1-methylxanthine (MIX) from G. D. Searle \& Co., Chicago, IL, USA. $\mathrm{PGE}_{2}$ (prostaglandin $\mathrm{E}_{2}$ ) was a gift from Dr. J. Pike, Upjohn Co., Kalamazoo, MI, USA; $\mathrm{L}-\left[1-{ }^{14} \mathrm{C}\right]$ ornithine $(49.2 \mathrm{mCi} / \mathrm{mmol})$ and $\left[{ }^{3} \mathrm{H}\right]$ thymidine $\left(\left[{ }^{3} \mathrm{H}\right] \mathrm{Tdr}\right.$, $80 \mathrm{Ci} / \mathrm{mmol}$ ) were obtained from New England Nuclear, Boston, MA, USA. The aqueous (ACS) counting scintillation solution was purchased from Amersham, Arlington Heights, IL, USA.

The Lux plastic coverslips were from Flow Laboratories, Newbury Park, CA, USA, the tissue culture cluster 24 came from Costar, Cambridge, MA, USA. Plastic $35 \mathrm{~mm}$, and $60 \mathrm{~mm}$ petri dishes were from Corning Glass Works, Corning, NY, USA. The center wells and rubber stoppers were purchased from Kontes, Vineland, NJ, USA. The vials for the ODC assay were from Kimble, IL, USA.

\section{Epidermal Keratinocyte Cultures}

The primary keratinocyte and fibroblast cultures were prepared as described by Marcelo et al. [16]. Full-thickness skin from 20-30 neonatal $\mathrm{BALB} / \mathrm{c}$ mice is trypsinized $(0.25 \%)$ for $1 \mathrm{~h}$ at $37^{\circ} \mathrm{C}$. The trypsin is aspirated and a medium with $10 \%$ fetal bovine serum is added. The epidermis is manually separated from the dermis. The keratinocytes, i.e., basal, and a small number of spinous cells are removed by gentle shaking and scraping of the epidermis. The basal and the few spinous cells are further isolated from debris and any dermal fibroblasts by use of a discontinuous Ficoll gradient. After centrifugation the basal cells, found in the $20 \%$ Ficoll layer, are washed and counted, using $0.05 \%$ trypan blue. 0.5 to $2.0 \times 10^{6}$ trypan-blue-excluding cells are plated in Costar 24-well culture clusters, each well containing a round $15-\mathrm{mm}$ coverslip. The cells are grown in $5 \% \mathrm{CO}_{2}$, in air gassing at $32^{\circ} \mathrm{C}$ in Medium 199 , which contains $50 \mathrm{IU} / \mathrm{ml}$ of penicillin, $50 \mu \mathrm{g} / \mathrm{ml}$ of streptomycin, and $13 \%$ fetal bovine serum. The medium is changed every second day.

For preparation of the epidermal cell suspension, the same isolation procedure was used and, in addition, $0.1 \%$ soybean trypsin inhibitor was added to the medium as described by Perchellet and Boutwell [24].

\section{Fibroblasts}

The trypsin-separated dermis is minced and suspended in $0.25 \%$ collagenase in Dulbecco's PBS. The suspension is stirred for $30 \mathrm{~min}$ at $37^{\circ} \mathrm{C}$ and then is filtered through gauze and centrifuged at $258 \mathrm{~g}$ for $5 \mathrm{~min}$. The pellet is resuspended in $10 \mathrm{ml}$ of $\mathrm{M}-199+13 \% \mathrm{FBS}$ and layered over a Ficoll gradient.

Fibroblasts from the $12 \%-15 \%$ Ficoll interface are plated $\left(0.5 \times 10^{6}\right.$ cells $/ 15-\mathrm{mm}$ coverslips $)$ in $\mathrm{M}-199+13 \% \mathrm{FBS}+\mathrm{P} \& \mathrm{~S}$ and $5 \% \mathrm{PCO}_{2}$ in air gassing. Cultures are fed every second day.

\section{ODC Assays}

The ODC activity of the cells is determined using two different assay procedures: assay of intact, living epidermal cells in either monolayer
[27] or in cell suspension and assay of sonicated cell supernate fractions for enzyme activity [41]. A scheme of these assay procedures is presented in Fig. 1.

The assay for ODC using intact cell lines [23] and epidermal cells [27] has been reported. For the epidermal cells in culture, the coverslips with the intact adherent cell layers are rinsed twice with cold Dulbecco's PBS and are placed in vials and covered with $475 \mu 1$ of $0.05 \mathrm{M}$ sodium potassium phosphate buffer, $\mathrm{pH} 7.2$, containing dithiothreitol $(1 \mathrm{mmol} / 1)$, EDTA $(0.1 \mathrm{mmol} / 1)$, pyridoxal $\mathrm{PO}_{4}$ $(0.4 \mathrm{mmol} / \mathrm{l})$ and $1.8 \mathrm{~g} \mathrm{\%} \mathrm{NaCl}$. Absolute ethanol-fixed cultures are used as blank controls. The assay is initiated by adding $25 \mu \mathrm{l}$ $\mathrm{L}-\left[1{ }^{14} \mathrm{C}\right]$ ornithine $(1.25 \mu \mathrm{Ci}$ and $56 \mu \mathrm{M}$ ornithine, final concentration) to the vials. After capping, the vials are placed in a $37^{\circ} \mathrm{C}$ shaking waterbath for 45 or $60 \mathrm{~min}$. The reaction is terminated by adding $0.5 \mathrm{ml}$ of $1 \mathrm{~mol} / 1 \mathrm{citric}$ acid to the buffer. The vials are shaken at least an extra $30 \mathrm{~min}$ to allow all $\mathrm{CO}_{2}$ to be trapped in the centerwells containing trapping agent (1 part of 2-methoxy-ethanol to 2 parts of 2-amino-ethanol). The centerwells with the ${ }^{14} \mathrm{CO}_{2}$ reaction product are put in a 10-ml aqueous scintillation (ACS) fluid and are counted in a Packard Tri-Carb Scintillation Counter (Packard Instrument Co., Inc., Downers Grove, IL, USA, efficiency $81 \%$ for ${ }^{14} \mathrm{C}$ ).

One milliliter of $10 \% \mathrm{TCA}$ is added to the vial containing the buffer and the monolayers (coverslips). After scraping the cells from the coverslips, the TCA precipitate is centrifuged and the pellet dissolved in $1 \mathrm{ml}$ of $1 \% \mathrm{NaOH}$ and assayed for total protein [13].

The ODC assay of epidermal cells in suspension is done as described by Perchellet and Boutwell [24]. $2 \times 10^{6}$ cells $/ 0.8 \mathrm{ml}$ Eagle's medium are placed in $10-\mathrm{ml}$ corning tubes and $0.2 \mathrm{ml}$ of the dissolved reagents is added. $10^{-3} \mathrm{~mol} / 1 \mathrm{MIX}, 10^{-6} \mathrm{~mol} / 1$ cholera toxin (dissolved in $50 \mathrm{mmol} / 1$ Tris- $\mathrm{HCl}, \mathrm{pH} 7.5$, plus $3 \mathrm{~mol} / 1 \mathrm{NaN}_{3}, 1 \mathrm{mmol} / 1$ EDTA, $200 \mathrm{mmol} / 1 \mathrm{NaCl}), 10^{-3} \mathrm{~mol} / 18-\mathrm{BrcAMP}$ and $10^{-6} \mathrm{~mol} / 1$ 8 -BrcGMP is added to the cells $20 \mathrm{~min}$ before the addition of $10^{-6} \mathrm{~mol} / 1 \mathrm{TPA}$

All the samples contained $0.02 \% \mathrm{DMSO}$, including the control cells. While being shaken, the cells are incubated at $37^{\circ} \mathrm{C}$ in $95 \% \mathrm{O}_{2}-$ $5 \% \mathrm{CO}_{2}$ for $5 \mathrm{~h}$. The incubation is stopped by adding $2 \mathrm{ml}$ of ice-cold Eagle's medium. After centrifugation for $20 \mathrm{~min}$ at $120 \mathrm{~g}$, cells are resuspended in $200 \mu 125 \mathrm{mmol} / \mathrm{l}$ Tris- $\mathrm{HCl}$ buffer containing $4 \mathrm{mmol} / 1$ dithiothreitol, $1 \mathrm{mmol} / 1$ EDTA and $0.2 \mathrm{mmol} / 1$ pyridoxal- $5^{\prime}-$ phosphate (assay buffer); these are used in the intact cell assay; $25 \mu 1$ of $\mathrm{L}-\left[1-{ }^{14} \mathrm{C}\right]$ ornithine + cold ornithine is added to the tubes to give a final specific activity of $0.5 \mathrm{mCi}\left[{ }^{14} \mathrm{C}\right]$ in $0.4 \mathrm{mmol} / 1$ ornithine. For the ODC activity assay using the cell supernate, the cells are resuspended in $300 \mu l$ of the assay buffer and are sonicated (Sonifier, Branson Sonic Porall Co.) on ice 5X, 1-s pulses, $50 \%$ output.

After centrifugation at $2,000 \mathrm{~g}$ for $15 \mathrm{~min}, 200 \mu \mathrm{l}$ of the supernate is used for the ODC assay as described by Yuspa et al. [41] and $100 \mu 1$ is used for protein determinations [13].

The results of the ODC assay are expressed as pmol ${ }^{14} \mathrm{CO}_{2} / \mathrm{mg}$ protein per 45 or $60 \mathrm{~min}$. The data are presented as \% control, i.e., treated cell value divided by the control cell value $\times 100$.

Effect of Various Parameters on the ODC Activity of Intact, Growing Epidermal Cell Cultures

TPA or 8-BrcAMP Effect. On the first day of cell culture growth, i.e., $8 \mathrm{~h}$ after plating, $5 \times 10^{-8}$ or $1 \times 10^{-7} \mathrm{~mol} / 1 \mathrm{TPA}$, or $10^{-3} \mathrm{~mol} / 1$ 8-BrcAMP was added to the medium, and ODC activity was measured at various times thereafter. In the experiments using 2- to 8-day-old cultures, the cells were exposed to TPA for $8-12 \mathrm{~h}$, and for $9-14 \mathrm{~h}$ to 8 -BrcAMP prior to the intact cell ODC assay.

Serum Effect. To render the cells quiescent, the mouse epidermal cell cultures were plated in growth medium $(24 \mathrm{~h})$ and then grown in M-199 without FBS. The intact cells were then assayed for ODC activity and cell proliferation after 5 days. 
Fibroblast Effect. We investigated the influence of fibroblasts on the responsiveness of the keratinocytes to TPA and 8-BrcAMP. To accomplish this, neonatal mouse basal cells and fibroblasts were plated on separate $15-\mathrm{mm}$ coverslips. After 1 day, basal cell coverslips and fibroblast coverslips were placed together in one $35-\mathrm{mm}$ petri dish, sharing the same medium. After 6 days of culture in 1 petri dish, $10^{-7} \mathrm{~mol} / 1 \mathrm{TPA}$ or $10^{-3} \mathrm{~mol} / 1 \mathrm{8}$-BrcAMP was added and ODC assays were done on the individual coverslips $10-14 \mathrm{~h}$ later.

$P G E_{2}$ Effect. $\mathrm{PGE}_{2}\left(10^{-5} \mathrm{~mol} / 1\right.$ was added simultaneously with $10^{-7} \mathrm{~mol} / 1 \mathrm{TPA}$ or $10^{-3} \mathrm{~mol} / 1 \mathrm{8}$-BrcAMP to the medium $10-14 \mathrm{~h}$ prior to ODC assay.

Determination of Epidermal Cell Proliferation and DNA Assay

Cell cultures grown in 35-mm petri dishes were pulsed for $6 \mathrm{~h}$ with $1 \mu \mathrm{Ci} / \mathrm{ml}$ of $80 \mathrm{Ci} / \mathrm{mmol}\left[{ }^{3} \mathrm{H}\right] \mathrm{Tdr}$. The medium was then aspirated and the cell layers were rinsed twice with cold Dulbecco's PBS. The cells were scraped in $2 \mathrm{ml}$ of $6 \% \mathrm{TCA}$. The $6 \mathrm{ml}$ of $6 \%$ TCA was pooled and $1 \mathrm{ml}$ of this $6 \%$ TCA fraction was counted to determine the $\left.{ }^{3} \mathrm{H}\right] \mathrm{Tdr}$ acid soluble fraction.

The pellet was hydrolyzed in $3 \%$ perchloric acid (PCA) at $95^{\circ} \mathrm{C}$ for $15 \mathrm{~min}$ and cooled for $20 \mathrm{~min}$. After centrifugation, an aliquot of the supernates was counted to determine the incorporation of label into DNA and assayed for DNA by Burton's method [1].

\section{Results}

\section{Baseline Ornithine Decarboxylase Activity}

The ODC activity of noninduced control cultures is shown in Fig. 1, along with a schematic presentation of the three assays and protocols used in these studies. Assay of intact living epidermal cells (1 day old) resulted in an ODC activity of $3,950 \pm 500$ pmols of ${ }^{14} \mathrm{CO}_{2} / \mathrm{mg}$ protein per $60 \mathrm{~min}$. ODC activity, when assayed in intact, living cells maintained in short-term suspension cultures was $3,163 \pm 644$ pmols ${ }^{14} \mathrm{CO}_{2} / \mathrm{mg}$ protein/60 min. Assay of the ODC activity of supernates from disrupted, sonicated cells was $77 \pm 20$ pmols ${ }^{14} \mathrm{CO}_{2} / \mathrm{mg}$ protein $/ 60 \mathrm{~min}$, which was the same activity seen in supernates from homogenized epidermal cell monolayer cultures [27].

\section{TPA Induction of Epidermal Cell Proliferation and $O D C$ Activity}

$10^{-7}$ and $10^{-8} \mathrm{~mol} / 1$ TPA was added to the epidermal cell cultures on day 2 of growth. Measurement of the $\left[{ }^{3} \mathrm{H}\right] \mathrm{Tdr}$ incorporation into DNA after a 6-h terminal labeling period on day 7 showed an average 2.7 -fold stimulation of epidermal cell proliferation (Table 1, $n=12$ ). These results are similar to those reported by Yuspa et al. [40] and Samsel et al. [33].

Figure 2 presents the results of ODC activity studies $(n=49)$ in intact living cells using $10^{-7}$ and $5 \times 10^{-8} \mathrm{~mol} / 1$ TPA. When TPA was added for 4 , and up to $18 \mathrm{~h}$ to the newly plated cultures (8-h-old), slight increases in ODC activity were often observed. These

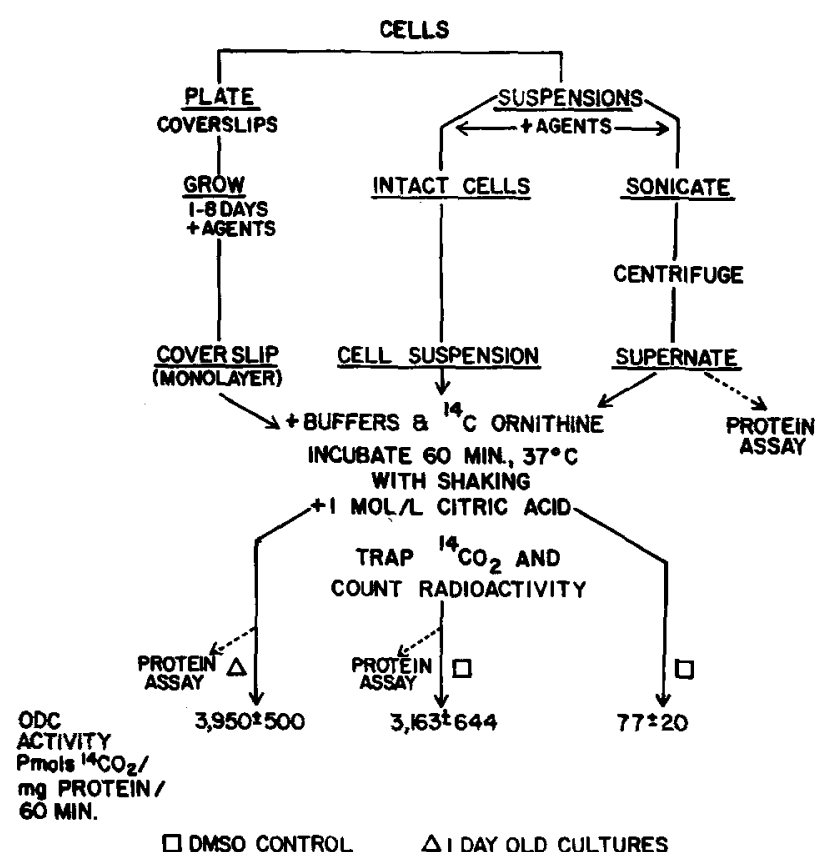

Fig. 1. Schematic presentation of the ornithine decarboxylase assay protocols and systems used in this study

Table 1. Effect of tetradecanoyl phorbol acetate (TPA) on proliferation of neonatal mouse keratinocyte cultures. $10^{-7}$ to $10^{-8} \mathrm{~mol} / 1$ TPA was added to the medium on Day $=2$ of culture and $\left[{ }^{3} \mathrm{H}\right] \mathrm{Tdr}$ uptake was measured on Day $=7$ of culture; mean \pm SEM of percent control (cpm/ $/ \mu \mathrm{g}$ DNA)

Percent control cpm $\left[{ }^{3} \mathrm{H}\right] \mathrm{Tdr} / \mu \mathrm{g}$ DNA

\begin{tabular}{ll}
\hline Control & TPA \\
\hline $100 \%$ & $276 \pm 82$ \\
\hline
\end{tabular}

$n=12 ; P<0.025$; statistical analysis used is Student's paired $t$-test

were only $50 \%-70 \%$ above the control values. Statistical analysis of the data showed only a slight significant increase of ODC activity $12 \mathrm{~h}$ after addition of TPA. There was no significant increase of ODC activity when TPA was added to the 2- to 8-day-old cultures $8-10 \mathrm{~h}$ prior to the intact cell ODC assay. We concluded that no consistent and significant induction of epidermal cell ODC activity by TPA occurred over the 8-day time span studied.

\section{8-BrcAMP Induction of Epidermal Cell ODC Activity}

Cyclic AMP analogs (dibutyryl and 8-Bromo cyclic AMP) and cholera toxin, an irreversible activator of adenylate cyclase are epidermal cell mitogens $[6,14$, 15): $10^{-3} \mathrm{~mol} / 18$-BrcAMP causes a $150 \%$ increase in epidermal cell culture proliferation approximately $24 \mathrm{~h}$ after addition, while the greatest mitogenic effect is seen 

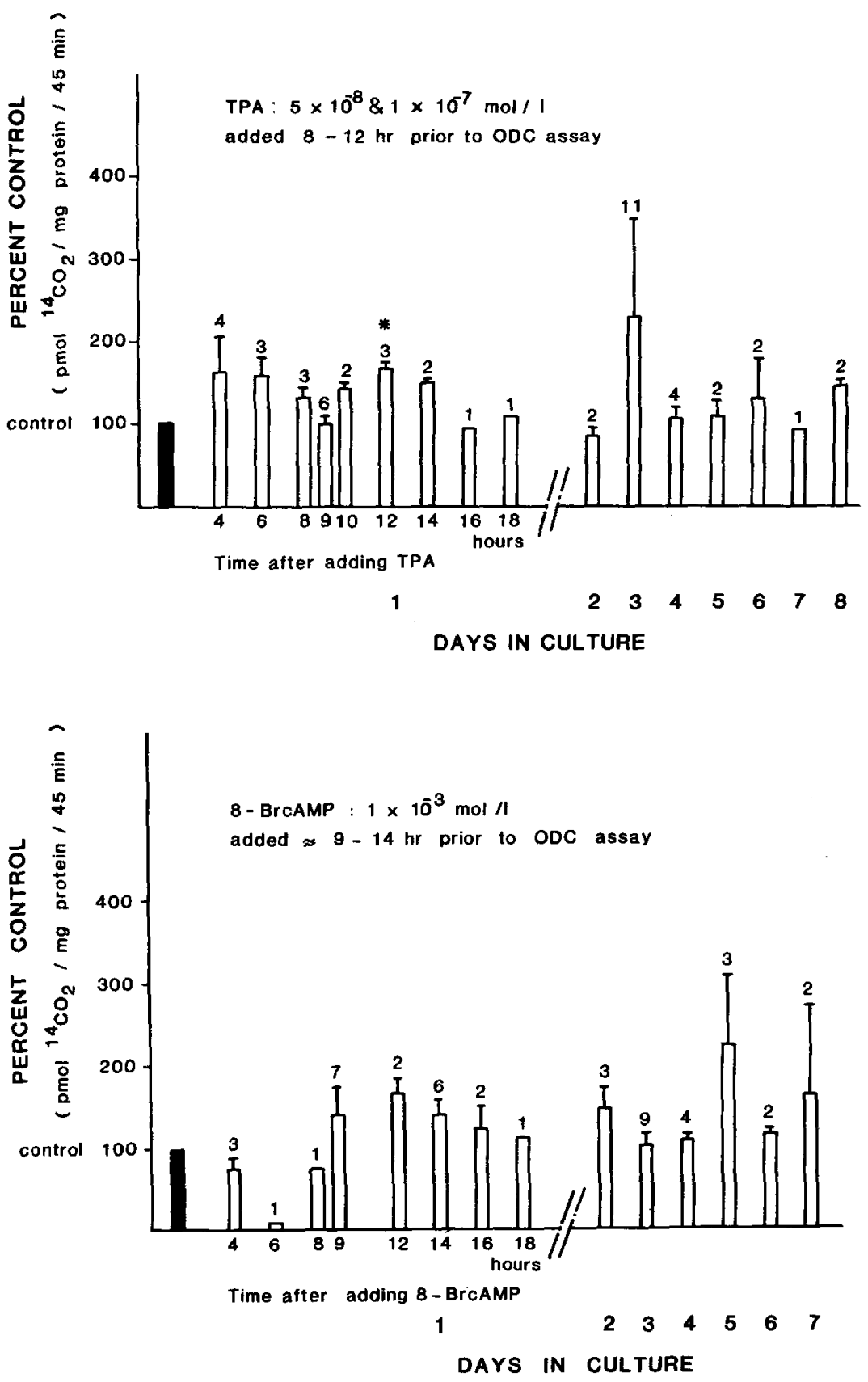

Fig. 2. Minimal induction of intact keratinocyte ODC activity by tetradecanoyl phorbol acetate $10^{-7}$ or $5 \times 10^{-8} \mathrm{~mol} / 1 \mathrm{TPA}$ was added 4,6 , $8,9,10,12,14,16$, and $18 \mathrm{~h}$ before assay to freshly plated (8-h-old) basal cells, and $8-12 \mathrm{~h}$ prior to ODC assay of 2- to 8-day-old cultures growing on coverslips. The numbers above the bars represent the number of replicate $\mathrm{ex}$ periments; $n=49$. The data are presented as mean \pm SEM of 3-11 experiments or the average \pm range of 2 experiments. Each assay was done in triplicate. Statistical analysis used was Student's paired $t$-test. ${ }^{*} P=0.025$; all other $P$ values were $P \geq 0.200$; : Control $=100 \%$
Fig. 3. Minimal induction of intact keratinocyte ODC activity by 8-bromocyclic AMP. $10^{-3} \mathrm{~mol} / 1$ 8-BrcAMP was added $4,6,8,9,12,14,16$, and $18 \mathrm{~h}$ before assay to freshly plated (8-h-old) cells, and $9-14 \mathrm{~h}$ prior to ODC assay of 2- to 7-day-old intact cultures growing on coverslips. The numbers above the bars represent the number of replicate experiments; $n=46$. The data are presented as mean \pm SEM of 3-9 experiments or the average \pm range of 2 experiments. Each assay was done in triplicate. Statistical analysis used was Student's paired $t$-test. The $P$ value was $P>0.200$ for all time points. Control value $=100 \%$
4 days after the growth of the cells in the medium containing 8-BrcAMP [14].

This most potent mitogenic concentration of 8 BrcAMP $\left(10^{-3} \mathrm{~mol} / 1\right.$ was added to newly plated basal cell cultures ( 8 -h-old) $4-8 \mathrm{~h}$ before intact cell ODC assay. As presented in Fig. 3 , an approximate $50 \%$ induction of the ODC activity of the cells was seen $9-18 \mathrm{~h}$ after the 8-BrcAMP was added. No induction of ODC activity by this cAMP analog was observed prior to the 9-h time point.

8-BrcAMP was then added $9-14 \mathrm{~h}$ prior to the ODC assay of 2- to 8-day-old cultures. A sporadic twofold increase in ODC activity was seen in the treated cultures, always with a large variation in the values (Fig. 3). The small and nonsignificant induction of ODC activity by 8 -BrcAMP was seen in $65 \%$ of the experiments ( $n=46$ ) done in this study.

\section{Putative Modulators of $O D C$ Induction by TPA and 8-BrcAMP}

Neither a large nor consistent induction by TPA or 8-BrcAMP was seen in our studies. Therefore, a group of experiments was carried out, which were designed to 
Table 2. Putative modulators of ODC: effects on TPA and 8BrcAMP induction

a) Serum

\begin{tabular}{lcc}
\hline Day $=6$ & Percent control & \\
\cline { 2 - 3 } & $13 \%$ Fetal bovine serum & No serum \\
\hline Control & $100 \pm 19 \%$ & $100 \pm 22 \%$ \\
& $(599 \pm 113)^{\mathrm{a}}$ & $(424 \pm 91)^{\mathrm{a}}$ \\
TPA & $80 \%$ & $178 \%$ \\
8-BrcAMP & $110 \%$ & $137 \%$ \\
One day after plating, half of the cultures were grown in M-199 with \\
no serum
\end{tabular}

b) Cocultured epidermal and dermal cells

\begin{tabular}{lcc}
\hline Day $=7$ & Epidermal cells & Fibroblasts \\
\hline Control & $100 \pm 12 \%$ & $100 \pm 11 \%$ \\
& $(846 \pm 100)^{\mathrm{a}}$ & $(1,570 \pm 178)^{\mathrm{a}}$ \\
TPA & $73 \%$ & $95 \%$ \\
8 -BrcAMP & $75 \%$ & $70 \%$
\end{tabular}

The cells, each grown on coverslips, shared common medium to which the drugs were added

\begin{tabular}{lcc}
\hline c) $\mathrm{PGE}_{2}$ & & \\
\hline $\begin{array}{l}\text { Days } 1 \text { and } 3 \\
(n=2)\end{array}$ & No PGE & $\begin{array}{l}\text { Plus } \mathrm{PGE}_{2} \\
\left(10^{-5} \mathrm{~mol} / \mathrm{l}\right)\end{array}$ \\
\hline Control & $100 \pm 4$ & $100 \pm 16$ \\
& $(1,165 \pm 46)^{\mathrm{a}}$ & $(958 \pm 155)^{\mathrm{a}}$ \\
TPA & $125 \%$ & $152 \%$ \\
8 -BrcAMP & $108 \%$ & $118 \%$ \\
\hline
\end{tabular}

ODC assay was carried out $10-14 \mathrm{~h}$ after drug addition in triplicates or quadruplicates. $10^{-3} \mathrm{~mol} / 1 \mathrm{1} 8$-BrcAMP and $10^{-7} \mathrm{~mol} / \mathrm{l} \mathrm{TPA}$ concentrations were added

a Control ODC activity in $\mathrm{pmol}{ }^{14} \mathrm{CO}_{2} / \mathrm{mg}$ protein $/ 45 \mathrm{~min}$. These values for ODC activity are characteristic of 1 -week-old cultures [27]

thest the effect of possible modulators of ODC activity on the induction of this enzyme by TPA and 8-BrcAMP (Table 2).

A. Is a quiescent, i.e., nondividing, cell population necessary for maximal induction of ODC by TPA or 8-BrcAMP?

The cultures were grown in serum-free medium for 5 days. This decreased the rate of $\left[{ }^{3} \mathrm{H}\right] \mathrm{Tdr}$ incorporation by the cells into DNA by $70 \%$ (data not shown). Cells grown in the serum-free medium showed no change in the baseline ODC activity when compared to cells grown in $13 \%$ FBS growth medium (Table 2). TPA and 8-BrcAMP slightly, but not significantly, induced the ODC activity of the cells grown in the serum-free medium. Therefore, arrest of epidermal cell growth had no effect on either the baseline or induced ODC activity of the epidermal cell cultures.
B. Is the presence of fibroblasts necessary for 8BrcAMP and TPA to maximally induce epidermal cell ODC activity?

Dermal fibroblasts and epidermal basal cells were cocultured, each grown on separate coverslips and a shared common medium to which TPA or 8-BrcAMP was added. Neither TPA- nor 8-BrcAMP-induced $\mathrm{ODC}$ activity was measured in the intact epidermal cell assay. No induction of fibroblast ODC by these agents was seen, although the dermal fibroblasts did have a high baseline ODC activity (Table 2).

C. Is the presence of $\mathrm{PGE}_{2}$ necessary for 8-BrcAMP or TPA induction of ODC to occur?

As shown in Table 2, exogenously added $\mathrm{PGE}_{2}$ did not significantly influence the induction of ODC by either agent.

\section{Comparison of Supernate and Whole Epidermal Cell ODC Assays Using Stimulated Suspension Cultures}

$10^{-3} \mathrm{~mol} / 1$ 8-BrcAMP, and $10^{-7}$ and $10^{-8} \mathrm{~mol} / 1 \mathrm{TPA}$ stimulate epidermal cell proliferation $([14,40]$; this report). Additionally, $10^{-6} \mathrm{~mol} / 1$ cholera toxin, $10^{-3} \mathrm{~mol} / \mathrm{l} \mathrm{MIX}$, and $10^{-6} \mathrm{~mol} / 1 \mathrm{8}-\mathrm{BrcGMP}$ affect epidermal cell proliferation and differentiation [14]. Most of these agents, at these concentrations, have been reported to induce epidermal cell ODC activity in adult mice [24]. Experiments were designed to test the ODC activity of the freshly isolated epidermal cells of neonatal mice in short-term suspension cultures, which had been treated for $5 \mathrm{~h}$ with these agents. Both intact whole-cell and sonicated-cell supernate assays were carried out. In Table 3 are presented the results of these assays along with a summary of the results reported by Perchellet and Boutwell [24]. Both adult [24] and neonatal epidermal cells in suspension when treated with either MIX, cholera toxin, TPA or MIX plus TPA or cholera toxin plus TPA, showed an induction of ODC activity ranging from 2- to 18 -fold in magnitude. Additionally, 8-BrcAMP and 8-BrcGMP both induced ODC activity 3- to 4-fold. The manyfold induction of ODC activity through all these agents was observed only when the cells were ruptured by sonication and the supernates were assayed for ODC activity. When cells treated in parallel suspension cultures were simultaneously tested using the intact cell ODC assay, no significant induction of ODC activity was seen (Table 3).

\section{Discussion}

Epidermal cells respond to TPA and cyclic-AMPelevating stimuli by hyperproliferation, both in vivo 
Table 3. The ODC activity of adult and neonatal isolated epidermal cells in short-term suspension cultures

\begin{tabular}{|c|c|c|c|}
\hline & \multicolumn{2}{|c|}{ Supernatant $(\%)$} & \multirow{2}{*}{$\begin{array}{l}\text { Whole-cel } \\
\text { assay (\%) } \\
\text { Neonatal }\end{array}$} \\
\hline & Adult [24] & Neonatal $^{a}$ & \\
\hline $\operatorname{MIX} 10^{-3} \mathrm{~mol} / 1$ & 294 & $564 \pm 162$ & $167 \pm 57$ \\
\hline $\mathrm{CT} 10^{-6} \mathrm{~mol} / 1$ & 328 & 222 & $59 \pm 8$ \\
\hline TPA $10^{-6} \mathrm{~mol} / 1$ & 1,176 & $736 \pm 185$ & $136 \pm 65$ \\
\hline $\begin{array}{l}10^{-3} \mathrm{~mol} / 1 \mathrm{MIX} \\
\quad+10^{-6} \mathrm{~mol} / 1 \mathrm{TPA}\end{array}$ & 3,300 & $1,832 \pm 499$ & $194 \pm 55$ \\
\hline $\begin{array}{l}10^{-6} \mathrm{~mol} / 1 \mathrm{TPA} \\
\quad+10^{-6} \mathrm{~mol} / \mathrm{CT}\end{array}$ & 2,576 & $378 \pm 82$ & $85 \pm 37$ \\
\hline $\begin{array}{l}\text { 8-BrcAMP } \\
10^{-3} \mathrm{~mol} / 1\end{array}$ & - & $407 \pm 41$ & $69 \pm 31$ \\
\hline $\begin{array}{l}\text { 8-BrcGMP } \\
\qquad 10^{-6} \mathrm{~mol} / 1\end{array}$ & - & $313 \pm 71$ & 49 \\
\hline
\end{tabular}

$n=2-4$, each assay was run using triplicates or quadruplicates $\mathrm{CT}=$ cholera toxin; $\mathrm{MIX}=3$-isobutyl-1-methylxanthine

a ODC activity expressed as \% DMSO control $(=100)$; the control $O D C$ assay values were almost equivalent to blank values in our supernatant assay. When using suspended epidermal cells we saw greater variability in ${ }^{14} \mathrm{CO}_{2}$ pmols/mg $\mathrm{h}$ values than when we used plated cells

$[11,21]$ and in vitro $[14,15,33,40,41]$. In vivo, the hyperproliferation induced by both agents may correlate with the induction of ODC activity $[21,25]$, thus suggesting an association between epidermal hyperplasia and induced ODC activity.

Isolated cell systems allow manipulations that are difficult, if not impossible to do in vivo. Therefore, cells in culture are primarily used in studies of both the molecular events that occur during TPA-induced hyperplasia and ODC activation, and of the role that cAMP might play in these interactions. Recent work, however, using both in vivo and in vitro models, mainly serves to illustrate the complexity of the polyamine system.

At present it is known that some but not all epidermal hyperplastic stimuli are associated with the induction of ODC activity $[17,18]$. While in vitro studies have demonstrated TPA induction of ODC activity in epidermal cells [41], other work with ceil cultures suggests that hyperproliferation and ODC induction are not always concordantly expressed [22]. Moreover, it is still uncleat as to whether there are interactions between cAMP and/or cGMP-activated mechanisms, and TPA induction of hyperplasia and ODC activity [19, 24, 25].

Our studies showed that the method of ODC analysis determined the magnitude of ODC induction measured when cells were challenged with epidermal mitogens. The results indicated that when epidermal cells were exposed in vitro to various hyperplastic agents, an induction of ODC activity was seen only when the assay was done using supernates from disrupted sonicated cells as the enzyme source. Simultaneous assay of cells from the same primary culture, grown both in suspension and in monolayer, showed no significant or consistent induction of ODC when the intact cell assay was used ([27]; this paper; Roseeuw, unpublished data).

Intracellularly, ODC has a biologic half-life of $10-$ $20 \mathrm{~min}$ [29] and the growth condition of the cells can lengthen the half-life of the enzyme [9]. ODC activity appears to be controlled by inhibitory proteins, called ODC-antizymes, the synthesis of which is induced by putrescine, spermidine, and spermine [8]. Therefore, there is negative feedback regulation of ODC by the end products of the reaction it catalyzes. Recently, Weeks et al. [39] reported that when the ODC activity of treated mouse epidermis treated by sonicated TPA is measured in the presence of putrescine, almost absolute inhibition of ODC induction is seen. Thus, ODC is an enzyme that has a short a variable half-life; its intracellular activity is controlled by specific protein inhibitors (ODC antizymes) which are, in turn, induced by the end products of ODC activity, the polyamines.

The simplest interpretation of the results of the studies described in this report is that ODC is subject to stringent intracellular control mechanisms which appear to be lost when the isolated enzyme is assayed. It is possible that some types of proliferative stimuli cause changes in overall cell metabolism, which could result in the apparent induction of ODC activity when the enzyme is assayed using disrupted cell preparations. For example, one possible metabolic change induced by proliferative stimuli might be the lengthening of the half-life of the ODC (and other) enzymes while the cell adapts to the hyperproliferative state. This increased half-life would not result in the increase of ODC activity when the cellular control mechanisms were operating. However, when isolated, a lengthening in the half-life of ODC might translate into an apparent twoto tenfold increase in the activity of the enzyme.

This explanation becomes more plausible when the stability of the ODC enzyme in intact cells is compared with its stability in sonicated cell supernates (Fig. 1, Table 3). In intact cells, ODC has a stable and very high enzymatic activity. Manipulation of culture conditions which might have changed the activity of normal or induced cell ODC, i.e., the growth rate of the cells, the medium levels of $\mathrm{PGE}_{2}$, or the presence of fibroblasts, did not affect the control or stimulated cell ODC activity. On the other hand, the baseline ODC activity of epidermal cell supernates is often not measurable, demonstrating the viability and variability of this enzyme once it is extracted from the cell. 
We therefore have concluded from these studies that there is no correlation between ODC induction, and cyclic AMP- or TPA-induced hyperproliferation, also implying that cAMP-induced events are not involved in the induction of epidermal ODC. This study and our continuing work on intracellular polyamine content and transport [28] suggests that the polyamine metabolism of these cells is a stable, complex, and protected function, thus identifying the polyamine system as being critical to the maintenance of epidermal cell growth.

Acknowledgements. We would like to thank Dr. Elizabeth A. Duell for stimulating discussions about this work. This investigation was supported by grants from NIH AM 26009-03 and AM 07197-04, and by "Het Fonds Voor Geneeskundig Wetenschappelijk Onderzoek" and the Vrije Universiteit Brussels, Belgium.

\section{References}

1. Burton K (1968) Determination of DNA concentration with diphenylamine. Methods Enzymol 12:163-166

2. Fozard JR, Part ML, Prakash NJ, Grove J, Schechter PJ, Sjoerdsma A, Koch-Weser J (1980) L-Ornithine decarboxylase: an essential role in early mammalian embryogensis. Science 208:505-508

3. Fulton DS, Levin VA, Lubich WP, Wilson CB, Marton LJ (1980) Cerebrospinal fluid polyamines in patients with glioblastoma multiforme and anaplastic astrocytoma. Cancer Res $40: 3293-3296$

4. Fürstenberger G, Marks F (1978) Indomethacin inhibition of cell proliferation induced by the phorbolester TPA is reversed by prostaglandin $E_{2}$ in mouse epidermis in vivo. Biochem Biophys Res Comm 84:1103-1111

5. Fürstenberger $G$, Richter H, Fusenig NE, Marks F (1981) Arachidonic acid and prostaglandin $E_{2}$ release and enhanced cell proliferation induced by the phorbolester TPA in a murine epidermal cell line. Cancer Lett 11:191-198

6. Green H (1978) Cyclic AMP in relation to proliferation of the epidermal cell: a new view. Cell 15:801 -811

7. Haddox MK, Magun BE, Russell DH (1980) Ornithine decarboxylase induction during $G_{1}$ progression of normal and Rous sarcome virus-transformed cells. Cancer Res 40:604-608

8. Heller IS, Fong WF, Canellakis ES (1976) Induction of a protein inhibitor to ornithine decarboxylase by the end products of its reaction. Proc Natl Acad Sci USA 73:1858-1862

9. Hogan BL, Murden S (1974) Effect of growth conditions on the activity of ornithine decarboxylase in culture hepatoma cells. J Cell Physiol 83:345-352

10. Kudlow JE, Rae PA, Gutman NS, Schimer BP, Burrow GN (1980) Regulation of ornithine decarboxylase activity by corticotropin in adrenocortical tumor cell clones: roles of cyclic AMP and cyclic AMP-dependent protein kinase. Proc Natl Acad Sci USA $77: 2726-2771$

11. Kuroki T (1981) Induction by cholera toxin of synchronous divisions in vivo in the epidermis resulting in hyperplasia. Proc Nat1 Acad Sci USA 78:6958-6962

12. Lee EJ, Larkin PC, Sreevalsan T (1980) Differential effect of interferon on ornithine decarboxylase activation in quiescent Swiss 3T3 cells. Biochem Biophys Res Comm 97:301-308

13. Lowry $\mathrm{OH}$, Rosebrough NJ, Farr AL, Randall RJ (1951) Protein measurement with the Folin phenol reagent. J Biol Chem $193: 265-275$
14. Marcelo CL (1979) Differential effects on CAMP and cGMP on in vitro epidermal cell growth. Exp Cell Res 120:201-210

15. Marcelo CL, Duell EA (1979) Cyclic AMP stimulates and inhibits adult human epidermal cell growth. J Invest Dermatol $72: 279$

16. Marcelo CL, Kim YG, Kaine JL, Voorhees JJ (1978) Stratification, specialization and proliferation of primary keratinocyte cultures. J Cell Biology 79:356-370

17. Marks F, Bertsch S, Fürstenberger G (1979) Ornithine decarboxylase activity, cell proliferation and tumor promotion in mouse epidermis in vivo. Cancer Res $39: 4183-4188$

18. Marks F, Fürstenberger G, Kownatzki E (1981) Prostaglandin E-mediated mitogenic stimulation of mouse epidermis in vivo by divalent cation ionophore $\mathrm{A} 23187$ and by tumor promoter $12-\mathrm{O}-$ tetradecanoylphorbol-13-acetate. Cancer Res 41:696-702

19. Mufson RA, Astrup EG, Simsiman RC, Boutwell R (1977) Dissociation of increases in levels of $3^{\prime}: 5^{\prime}$-cyclic AMP and $3^{\prime}: 5^{\prime}-$ cyclic GMP from induction of ornithine decarboxylase by the tumor promoter 12-O-tetradecanoylphorbol-13-acetate in mouse epidermis in vivo. Proc Natl Acad Sci USA 74:657-661

20. Mufson RA, Simsiman RC, Boutwell RK (1977) The effect of the phorbol ester tumor promoters on the basal and catecholamine-stimulated levels of cyclic adenosine $3^{\prime}: 5^{\prime}$-monophosphate in mouse skin and epidermis in vivo. Cancer Res $37: 665-669$

21. O'Brien TG, Simsiman RC, Boutwell RK (1975) Induction of the polyamine-biosynthetic enzymes in mouse epidermis and their specificity for tumor promotion. Cancer Res $35: 2426-2433$

22. O'Brien TG, Lewis MA, Diamond L. (1979) Ornithine decarboxylase activity and DNA synthesis after treatment of cells in culture with 12-O-tetradecanoylphorbol-13-acetate. Cancer Res 39:4477-4480

23. Patterson MK Jr, Maxwell MD (1980) In situ assay for ornithine decarboxylase in tissue culture. Anal Bioch 104:452-456

24. Perchellet JP, Boutwell RK (1980) Enhancement by 3-isobutyl-1methylxanthine and cholera toxin of 12-O-tetradecanoylphorbol-13-acetate-stimulated cyclic nucleotide levels and ornithine decarboxylase activity in isolated epidermal cells. Cancer Res $40: 2653-2660$

25. Perchellet JP, Boutwell RK (1981) Effects of 3-isobutyl-1-methylxanthine and cyclic nucleotides on 12-O-tetradecanoylphorbol-13-acetate-induced ornithine decarboxylase activity in mouse epidermis in vivo. Cancer Res 41:3918-3926

26. Proctor M, Fletcher H, Shulka J, Rennert O (1975) Elevated spermidine and spermine levels in blood of psoriasis patients. J Inv Dermatol 65:409-411

27. Roseeuw DI, Duell EA, Marcelo CL (1982) Intact epidermal cell assay for ornithine decarboxylase activity. Arch Dermatol Res 273:137-148

28. Roseeuw DI, Marcelo CL, Voorhees JJ (1982) Active maintenance of cellular levels of polyamines by epidermal cells in culture. J Inv Dermatol 78:342

29. Russell DH, Snyder SH (1969) Amine synthesis in regenerating rat liver: extremely rapid turnover of ornithine decarboxylase. Mol Pharmacol 5:253-262

30. Russell DH (1973) Polyamines in growth - normal and neoplastic. In: Russel DH (ed) Polyamines in normal and neoplastic growth. Raven Press Publishers, New York, pp 1 - 14

31. Russell DH, Stawiski MA, Duell EA, Voorhees JJ (1976) Elevated polyamine metabolism in patients with psoriasis. Pharmacologist 18:157-165

32. Russell DH, Combest WL, Duell EA, Stawiski MA, Anderson TF, Voorhees JJ (1978) Glucocorticoid inhibits elevated polyamine biosynthesis. J Invest Dermatol 71:177-181

33. Samsel W, Fisher G, Kovar R, Fusenig NE (1974) The effect of the tumor-promoting agent 12-O-tetradecanoyl-phorbol-13acetate on proliferation and differentiation in primary cultures of 
mouse epidermal cells. Hoppe Seyler's Z Physiol Chem 355: 1245-1246

34. Scalabrino G, Pigatto P, Ferioli ME, Modena D, Puerari M, Caru A (1980) Levels of activity of the polyamine biosynthetic decarboxylases as indicators of degree of malignancy of human cutaneous epitheliomas. J Invest Dermatol 74:122-124

35. Schrode J, Folk JE (1978) Transglutaminase-catalyzed crosslinking through diamines and polyamines. J Biol Chem 253: $4837-4840$

36. Takigawa M, Ishida $H$, Takano T, Suzuki F (1980) Polyamine and differentiation: induction of ornithine decarboxylase by parathyroid hormone is a good marker of differentiated chondrocytes. Proc Natl Acad Sci USA 77:1481-1485

37. Verma AK, Boutwell RK (1981) Intracellular calcium and skin tumor promotion: calcium regulation of the induction of epidermal ornithine decarboxylase activity by the tumor promoter 12-O-tetradecanoylphorbol-13-acetate. Biochem Bioph Res Comm 101:375-383

38. Verma AK, Ashendel CL, Boutwell RK (1980) Inhibition by prostaglandin synthesis inhibitors of the induction of epidermal ornithine decarboxylase activity, the accumulation of prostaglandins, and tumor promotion caused by 12-O-tetradecanoylphorbol-13-acetate. Cancer Res 40:308-315

39. Weeks RG, Verma AK, Boutwell RK (1980) Inhibition by putrescine of the induction of epidermal ornithine decarboxylase activity and tumor promotion caused by $12-\mathrm{O}$-tetradecanoylphorbol-13-acetate. Cancer Res 40:4013-4018

40. Yuspa SH, Ben T, Patterson E, Michael D, Elgjo K, Hennings H (1976) Stimulated DNA synthesis in mouse epidermal cell cultures treated with 12-O-tetradecanoylphorbol-13-acetate. Cancer Res 36:4062-4069

41. Yuspa SH, Lichti U, Ben T, Patterson E, Hennings H, Slaga TJ, Colburn N, Kelsey W (1976) Phorbol esters stimulate DNA synthesis and ornithine decarboxylase activity in mouse epidermal cell cultures. Nature 262:402-404

Received August 27, 1983 